\title{
Young Jazz Musicians and Negotiation of Public Space In Yogyakarta Indonesia
}

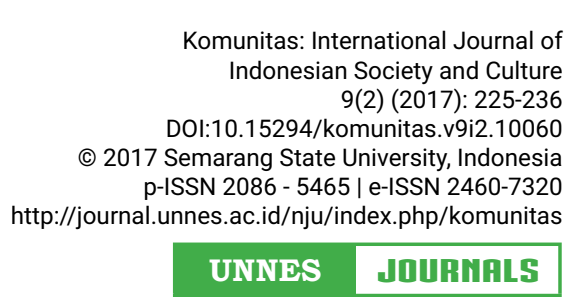

\section{Oki Rahadianto Sutopo ${ }^{1}$}

1Department of Sociology, Faculty of Social and Political Sciences, Universitas Gadjah Mada, Indonesia

Received: June 2017; Accepted: August 2017; Published: September 2017

\begin{abstract}
Using Bourdieusian approach, this article explores the reflexive strategies of young jazz musicians in order to develop their musical practices in a contemporary urban context of Yogyakarta, a city of culture and activism in Indonesia. In detail, the reflexive habitus (Sweetman 2003) will be explained as the manifestation of struggle in the field of cultural production (Bourdieu 1993). As an implication, young jazz musicians have to negotiate their musical practices with the reproduction of doxa and the representation of dominant agents in the jazz music field including the availability of public spaces in contemporary Yogyakarta. The resistance towards doxa will be explained based on the local narratives of the Yogyakarta jazz community as a mixture of the local and the trans-local scene (Bennett \& Peterson 2004). The reflexive strategy will be analysed through the lens of the youth culture perspective specifically as a manifestation of a mixture between postsubculture (Bennett 1999) and subculture (Blackman 2005). In their everyday musical practices, young jazz musicians produce their musical practices fluidly and flexibly as a lifestyle distinction as well as a form of everyday life resistance. In summary, this article shows the complexity of the musical processes of young jazz musicians in contemporary urban space of Yogyakarta, Indonesia.
\end{abstract}

\section{Keywords}

doxa; public space; young musicians; Yogyakarta; jazz

\section{INTRODUCTION}

In Indonesia, jazz as a form of cultural production reached a peak of popularity in the post -1998 reform era. This is not only an extraordinary phenomenon at a national level but also at a local level including Yogyakarta as a site of my participant observation. As a city of education and culture, the dynamic nature of contemporary Yogyakarta is mostly driven by creative university students, intellectuals and artists from various fields of cultural production. Based on my participant observation, contemporary Yogya- karta nowadays is in the process of transformation into a more touristic city which is extremely driven by capital infiltration in all aspect of everyday life. Thus capitalist production requires the capital owners to mobilize resources and create landscapes suitable to doing business (Farrugia 2014, p. 297). In Bourdieusian terminology, it can be argued that the logic of profit becomes

\footnotetext{
Corresponding author

JI. Sosio-Justisia No.2 Bulaksumur Yogyakarta

55281, Indonesia

Email

oki.rahadianto@ugm.ac.id
} 
the ultimate doxa at the heart of the dynamic nature of contemporary Yogyakarta. According to Bourdieu (1998) doxa is taken for granted reality where the natural and social worlds appear as self-evident. Different types of doxa characterize different fields, acting to orientate appropriate modes of perception (Myles 2004, p. 93). The operation and manifestation of doxa is included in the commodification process and privatization of public space ${ }^{1}$ which in the past was considered as a taken for granted 'arena' for musicians, artists and other social agents to produce their cultural products. This means that space is never neutral, it is inevitably always gendered, classed, perceive as inclusive for some and exclusive for others (Bloustien and Peters 2011). Furthermore, as city planning is constructed to serve the profitdriven tourism industry, the music product itself also gradually transformed into a commodity including jazz (Sutopo 2012). These conditions created an impact which forced social agents to negotiate not only their artistic practices and expression but also the availability of public space.

In order to understand the process of negotiations between social agents and the commodification and privatization of public space as a manifestation of doxa, it is useful to explore the point of view of young jazz musicians as social agents whom struggle in the hierarchical and various fields of cultural production. Young people through choice and coercion, are responding and negotiating contemporary economic and social changes as best they can through new and diverse ways (Wyn and White 200o, p. 167) including for young jazz musicians as a research subject in this article. The process of commodification as a result of the tourism industry can be analyzed as structural forces acting against multiply elements of youth culture because objectively, majorities of public space and cultural products are occupied by young people. In addition, negotiations imply a logical framework which highlights the aspect of youth as an agency which

1 For a discussion of public space in Yogyakarta using entry point of Jogja Fashion Week Carnival see Setiawan, Haryono and Burhan (2014). specifically will be focused on their creative strategies. I will take the analysis further by highlighting the concept of reflexive habitus (Sweetman 2003) as a form of cultural capital (Threadgold and Nilan 2009) and as an important entry point to explain their creative strategies in the context of the mixture between subculture (Blackman 2005) and post-subculture (Bennett 1999). It can be argued that the negotiations of public space in Yogyakarta are manifested in the occupation of jazz communities, public jam session and jazz on the street by young jazz musicians. I also argued that young jazz musicians produce their musical practices fluidly both as a lifestyle distinction as well as a form of everyday life resistance.

\section{RESEARCH METHODS: ENGAG- ING IN THE YOGYAKARTA JAZZ SCENES}

Before I explore and analyze further, I would like to share some methodological notes related to this research. This is important as a reflexive tool not only for me but also for the readers; it also important to clarify honestly some biases related to my position as a fluid and flexible insider (see Bennett 2002; Hodkinson 2002). This study employed participant observation as its main method. My participation in Yogyakarta jazz scene started in 2003 when I decided to move to Yogyakarta to continue my bachelor degree. Back in the day, Yogyakarta was a very attractive place for young people like me not only because of the high quality of higher education, but also for a young musician, Yogyakarta offers various music scenes compared to other cities in Indonesia. I was born and grew up in Solo, an industrial town one hour by train from Yogyakarta. Solo was totally different to Yogyakarta particularly related to the variety of music scenes. I grew up and played mostly USA/UK 7os-9os hard rock which spanned from Led Zeppelin, Deep Purple, Mr. Big, Bon Jovi and Guns 'N Roses especially in music festival competition. I recall that there were not many grassroots music communities except those which 
were based on rental music studios. After I moved to Yogyakarta, I got many chances to explore different genres of music including through fluidly joining several music communities. At that time, I was also a new student in a prestigious university; therefore I searched for lifestyle distinction (Bourdieu 1984) and aimed to take my career as a musician seriously by choosing to join the jazz scene in Yogyakarta. The on and off participation itself took place between 2003-2012.

As a newcomer in 2003, in order to adapt to the new field of the game I had to accept the rules of the game as taken for granted. I engaged in many of the jazz scene activities, from regular jam sessions in public to internal communities, doing regular gigs with standard jazz repertoires, giggin' in jazz festivals in Jakarta and also regularly hanging out with not only fellow young musicians but also senior musicians as well as patrons of Yogyakarta jazz scenes. Methodologically, these engagements as an insider gave me privileges to access first hand data, to participate in and feel the struggle in the field as well as be able to be reflexively aware of the unequal positions among social agents in jazz music scenes. Furthermore, it also gave me a privilege to experience the shift of dynamic nature in the jazz scenes. In 2007, I decided to move temporarily to Jakarta (the capital city of Indonesia) to chase my music career and continue my master degree. This was the moment when I detached with the Yogyakarta jazz scene; however, I decided to write a master thesis about the dynamic of power in the Yogyakarta jazz communities during 2002-2010 therefore my contacts with them continue. After I released three CDs with my band in Jakarta, in early 2011, I decided to move back to Yogyakarta to work as a sociology lecturer at Gadjah Mada University. However, I still continued my profession as a musician but rather than play regular gigs in the pubs, I preferred to produce my own DIY music albums with several bands in Yogyakarta. During this time, I still hung out and jammed with fellow jazz musicians but mostly I think more as a non-full time-insider. In 2013, I got a scholarship and moved to New- castle, Australia. In here, I do not engage in the jazz scene at all, however, I continue playing regularly in the pubs with a Glam Rock band and as a session bass player for many DIY music albums for Newcastle's singers and artists. In short, being a fluid and flexible insider gave me an important insight as well as relative freedom to be reflexive when I started to analyze young jazz musicians as a research subject in this article.

\section{SNAPSHOT OF YOGYAKARTA JAZZ SCENE AND YOUTH CULTURE}

Genealogically, the history of jazz in Yogyakarta can be traced back from the Dutch colonial era (see Sutopo 2010). Jazz as an imported cultural product was constructed as a manifestation of distinguished privileged class culture especially the Dutch and small local elites. Furthermore, related to space, jazz as a form of class distinction (Bourdieu 1984) was confirmed through an oral history interview in 2010 with two senior jazz observers from Yogyakarta who explained that jazz was usually performed in the Yogyakarta palace (Keraton Yogyakarta) and also societet (society) buildings (Sutopo 2010). During this era, young indigenous musicians whom performed jazz as a part of their youth culture were mostly highly educated especially based on the Dutch system of education and often their family had a close patron and clients' dominant-dominated relation with the colonizer which spanned from bureaucratic, trades and 'romantic' relationship based on slavery (see Baay 2017).

In the era of New Order regime/ Rezim Orde Baru (1965-1998), jazz as an elite youth cultural product was continuously reproduced. However, different to the Dutch colonial era, the image of jazz was reproduced as a manifestation of western culture, especially American culture, as a representation of progress in a sense of cultural evolution and hierarchical strata between the localnational and the international level. Contextually, the shift of jazz meaning is related to the grand design of the post-cold war Indonesian social, political and cultural program which was more oriented to American 
based-ideology of capitalism and modernization. This contrast with the Old Order regime/ Rezim Orde Lama (1949-1965) which was more projected into the direction of socialist/communist social, political and cultural program. In addition, in terms of space, jazz was played in hotels, restaurants and expanded into universities as well as annual jazz festivals (see Sutopo 2010). In this era, audiences of jazz came to include educated young people, academics and bureaucrats who represented the new middle class in Indonesia including Yogyakarta. In short, it can be described that jazz was still a modern manifestation of high culture.

In Yogyakarta as a city of education and culture, the New Order period became the crucial moment of identity formation of jazz as a part of subculture (Blackman 2005) and a mixture of local and trans local scenes (Bennett and Patterson 2004). Young jazz musicians at that time, which mostly came from highly educated background both in music/non-music universities, started to initiate regular meetings, produced and shared knowledge about jazz as well as actively maintaining a close relationship with patrons which included mainly jazz lovers whom possessed a high volume of economic, cultural and social capital (Bourdieu 1993). This included sharing of objectified cultural capital among jazz musicians and jazz lovers such as jazz records and jazz books which were still very rare and unfordable. At that time, access to jazz records and books for the Yogyakarta jazz scene mostly relied on the capacity of jazz lovers to import some of those products from America or Europe. In other words, the objectified cultural capital was not distributed equally (Bourdieu 1986). Furthermore, two-manifestations of regular meetings among jazz lovers were Jogja Jazz $C l u b$ and Wartajazz ${ }^{2}$. Through these mutual social relations, jazz musicians were able to occupy a strategic and safe meeting place (see Urry 2000) in order to continue their artistic practices and to expand their audi-

2 A DIY source of online jazz information and records distributor which is initiated by young jazz lovers during late 1990s. For further information, please check: www.wartajazz.com ences. On the other hand, jazz as a part of youth subculture represented its authenticity based on academic-pedagogical jazz (jazz sekolahan) and purity of jazz according to its American roots mostly in the era of 1920s-1950s. In the artistic practices, authenticity and purity of jazz was often reproduced through the playing of standard jazz based on Real book (see Sutopo 2010) as a source of boundedness and style identification among members of jazz subculture. In short, jazz as a form of subculture in the context of Yogyakarta was not part of resistance but as a form of cultural capital to create distinction among educated and middle class youth (Bourdieu 1984).

The authoritarian New Order regime of President Suharto ended in 1998 when he was forced to step down, as explained: "The movement that toppled Suharto, which grew explosively between March and May 1998, was concentrated among the middle classes in these cities and was led particularly by university students" (Aspinall and Berger 2001, p. 1007). On the other hand, post-reformation era in Indonesia also created a phenomenon of decentring knowledge/power (Foucault 1980) which in the field of cultural production was translated into the emergence of local culture/locality as well as its creative hybridizing strategy with global culture including jazz itself. Furthermore, the era of 'relative' freedom and decentring knowledge/power was translated in various ways by young jazz musicians as well as other members of jazz subculture in Yogyakarta. In contrast to the previous generation whom maintained its exclusivity not only among other music genres and other music communities including its scope of scenes, young jazz musicians in the period of post-reformation can be described as gradually shifting into the characteristic of post-subculture which was characterized by its flexibility and fluidity of membership. In other words, the forms of association and social gatherings in which young people become involved are not rigidly bound but rather assumed a more fluid, neo-tribal character (Bennett 1999, p. 614). However, it did not mean that it was fully transformed 
into post-subculture, objectively; there were always elements of subculture. It is better to describe the characteristic of Yogyakarta jazz as a mixture between subculture and post-subculture.

During post-reformation period, subjectively, young jazz musicians and jazz lovers in Yogyakarta no longer identified themselves as a part of elite class and produced a modern manifestation of high culture; although in reality, class discourse are still continuously reproduced. In contrast, there were massive cultural movement among jazz members to reconstruct the image of jazz to be more oriented towards grassroots. In this sense, grassroots were defined as embeddedness to local culture and also its capacity to be accepted by lower class segment. In short, they tried to expand the segments of jazz to cross the boundaries of class spectrum in contemporary Yogyakarta. Young jazz musicians together with senior musicians as strategic social agents in the field of cultural production actively tried to initiate a new form of jazz as a manifestation of third space, an ambivalent site where cultural meaning and representation have no primordial unity or fixity (Bhabha 2004). This new form of jazz product opened up a spatial politic of inclusion; it also opened a space for collaboration and contestation. Furthermore, the shift pattern also included the inclusiveness of jazz and its creative combination with other various forms of genres including metal, pop, dangdut ${ }^{3}$ and kroncong $^{4}$. Besides that, these also included their diversification of space of playing jazz which contrasted to the previous era which was more into elite places, nowadays, jazz in Yogyakarta can be found in grassroots communities, on the streets and in various rural areas, not exceptionally its innovative annual jazz festival, Ngayogjazz ${ }^{5}$ which takes

3 An Indonesian music style that represents a synthesis of local, Middle Eastern, Indian, and Western musical traditions.

4 An Indonesian music style which is heavily influenced by Portuguese music and instruments.

5 An annual jazz festival in Yogyakarta which often takes place in rural area and hybridize with local culture. For further information, please check: www.ngayogjazz.com and for an place in rural areas around Yogyakarta.

\section{STRATEGIES OF NEGOTIATION AGAINST LIMITED PUBLIC SPACE}

Bourdieu in his book The Field of Cultural

Production (1993) explains the complexities of struggle for maintaining and achieving upward mobility in the field of the game among social agents particularly in the field of cultural production. In order to contextualize Bourdieu's theoretical apparatus in the domain of youth culture, it needs to be understood that young jazz musicians occupy a peculiar position in the hierarchical field of struggle. In Yogyakarta jazz scene, the position of young jazz musicians can be described as in constant negotiations with dominant social agents as well as with other social agents who are not directly related but play an important role in the field, for example: the patrons (restaurants, dominant senior artists, universities, and jazz lovers etc. including local governments). Implicitly, this is not only related to the possession of capital (cultural, social and economic) in each individual but also genealogically related to the continuous reproduction of internal doxa in the Yogyakarta music scene itself as a representation of local/trans local music scenes (Bennett and Patterson 2004). On entering a new field of struggle, the existing habitus of social agents can be modified by the accumulation of relevant capital so they can have more chance to achieve higher position in the future. At the scope of individual level, in order to be a good player in the field of struggle (see Lamaison 1986), it is a must for young jazz musicians to be able to reflexively adapt and adjust as well as flexibly re-adapt and re-adjust to the unpredictable dynamic of doxa in the jazz field. In other words, the high volume of reflexivity as a form of cultural capital is important (see Threadgold and Nilan 2009). However, to be able to adapt and adjust internally in the music field is not enough; young jazz musicians also have to be able to be reflexively aware of the social

example of Ngayogjazz 2012 and 2014 video trailer on YouTube: https://www.youtube.com/ watch?v=me2pEUJETmM and https://www.youtube.com/watch?v=jjfSTSNc7OQ 
changes surrounding their environment. In other words, a reflexive orientation towards the contemporary environment may itself be regarded as a form of habitus, itself the outcome of an adaptation to - rather than a distinction from - the changing nature of the social terrain (Sweetman 2009, p. 543). Young jazz musicians' strategies to be able to survive internally in the jazz music field have been explored elsewhere by the author (see Sutopo 2010; 2012). In next the following pages, I will focus on young jazz musicians' strategies of negotiation against limited public space.

\section{JAZZ COMMUNITIES AND PUBLIC JAM SESSION AS AN ALTERNATIVE SPACE OF PRODUCTION}

For young jazz musicians who participate in the field of struggle, the availability of space is an important element during the process not only as a space to accumulate embodied cultural capital and knitting social capital (Bourdieu 1993), exploration of youth lifestyle (Bennett 2000) but also to promote themselves in public. However, in reality, the availability space does not exist without any interest from various social agents embedded in it. In Yogyakarta, it seems that there is lack of political commitments to provide public space for its citizen, there is a shift from public openness to private business that are able to access public facility. Based on my participant observation, there are two ideal types (see Perdue 1986) of space in relation to economic and symbolic interests in the case of Yogyakarta jazz scenes. Firstly, a space that is considered as a public arena for exclusive members and inclusive for others. As an ideal type, there are often overlaps between both participants. This type of 'public space' is characterized by its lack of economic interest which is mainly driven by the logic of profit accumulation. Instead, this type of public space is very productive to nurture various elements of jazz culture among young people. In everyday life, this space often runs by young musicians themselves together with senior musicians whom are voluntarily keen and have a deep commitment to maintain the sustainability of this type of public space. Contrast to the first type, the second type of space is dominantly driven by economic interest. Most of them are owned by local/national/transnational businessman and manifest into various types of restaurants, pubs and hotels all over Yogyakarta. In this place, most jazz activities are driven by interest to attract more audiences in order to give economic benefit for the venues. Sometimes this kind of place facilitates social events such as fundraisers and DIY album launch etc.; however, implicitly the main logic is to boost the profit for venues. In a different case, some community based-pubs/restaurants are in the middle position between public and profit interest. They support the jazz scenes' agenda but on the other hand, they need audiences in order to maintain the sustainability of their social business.

A high volume of reflexivity as a form of cultural capital (Threadgold and Nilan 2009) among young jazz musicians were shown in their creative strategies to be able to creatively create, engage and maintain the sustainability of free public space (first type) in this case jazz communities and public jam session as alternative spaces of artistic productions. However, the ability and endurance to maintain public space were not organized by young jazz musician themselves; in contrast, as the field of cultural production is characteristically hierarchical, therefore young jazz musicians have to be able to maintain a close relationship with senior musicians and patrons whom 'informally' and 'culturally' held dominant positions in the field. In Bourdieusian terminology (1993), young jazz musicians have to be able to convert their stock of social capital into 'more' strategic social capital. Realistically, compared to senior musicians and patrons, young jazz musicians possess relatively less volume of various valuable forms of capital. However, in order to boost their music career and achieve upward mobility in the field of cultural production, young jazz musicians have to increase their volume of capital. Directly playing in the second type of public space which is driven by economic interest will be impossible for two reasons. Firstly, 
this profit driven public space already had their own doxa (Bourdieu and Wacquant 1992) and continuously reproduced in order to maintain their distinct audiences. The manifestation of doxa is not only in matter of jazz style but also the level of sophistication related to jazz skills. Secondly, these profit driven public spaces are seldom providing space to have a jam session and comfortable situations to share particular forms of cultural capital. Thus it can be argued that spaces are produced by unequal social and power relations and are a constitutive dimension of the conditions that structure young peoples' transitions (Farrugia 2014, p. 297) including young jazz musicians in this case. Based on those reasons, there are no other alternatives for young jazz musicians than to join existing jazz communities and participates in public jam session, thus the role of place remains central to young people's choices, habits and behaviors (Fraser et al 2017, p. 238). This strategy can not only be read as their individual reflexive strategy but also symbolically, it represents young jazz musicians act of resistance against privatization and commodification of public spaces as well as lack of local government initiatives to facilitate space for nurturing youth culture. Thus, theoretically, young jazz musicians produce heterodoxa to counter the existing orthodoxa (see Bourdieu 200o) of privatization and commodification of public space.

As an alternative space of production, jazz communities take an important role as a source of valuable forms of capital especially social and cultural capital for young jazz musicians. Vertically, jazz communities facilitate the transmission of capital from senior musicians to younger musicians as well as shared among young jazz musicians themselves. The temporal flexibility of jazz communities also facilitates an alternative space of embodiment process among young jazz musicians; this is not only as a learning mechanism for newcomer musicians but also for mastering purpose for advanced young musicians. From the musician's point of view, the process of embodiment of mastering music instruments is one of important and strategic forms of cultural capital to be a professional musician (see Wacquant 2004). In this case, jazz communities are able to facilitate this process of embodiment since there are always availability of fellow senior/junior musicians whom happily share, support and criticize positively (sometimes harshly!) during the process of learning and mastering. Jazz communities also play a role as a space to accelerate the embodiment of cultural capital which most of young musicians did not obtain intensively from previous socialization. In other words, it points out the importance of music community as space to nurture secondary habitus which is defined as any system of transposable schemata that becomes grafted subsequently, through specialized pedagogical labor that is typically shortened in duration, accelerated in pace and explicit in organization (Wacquant 2014, p. 7). Horizontally, jazz communities as a free public space facilitate the durability of social interactions among young jazz musicians. Based on my observation, young jazz musicians often spend almost 24 hours hanging out with their fellow musicians. They also help each other not only related to gigs but also in every aspect of everyday life. Often their social interactions are going further by having serious conversations about romance, family problem and future career plans. In a long term, these durable interactions create a very strong solidarity among them and useful as a valuable stock of capital when young musicians decide to move to different cities to chase advance music careers. ${ }^{6}$ In short, the availability of jazz communities as an alternative public space is important for the process of artistic production and transmission of valuable forms of capital for young jazz musicians.

Besides jazz music communities, creating and maintaining a public space for a musical jam session is also part of the young jazz musicians and senior musicians' strategies to resist against the privatization and commodification of public spaces in Yogya-

6 For specific discussion on the durability of social capital, reflexivity, timing and young musicians in Yogyakarta, Jakarta and Bali, see Sutopo, Threadgold and Nilan (2017). 


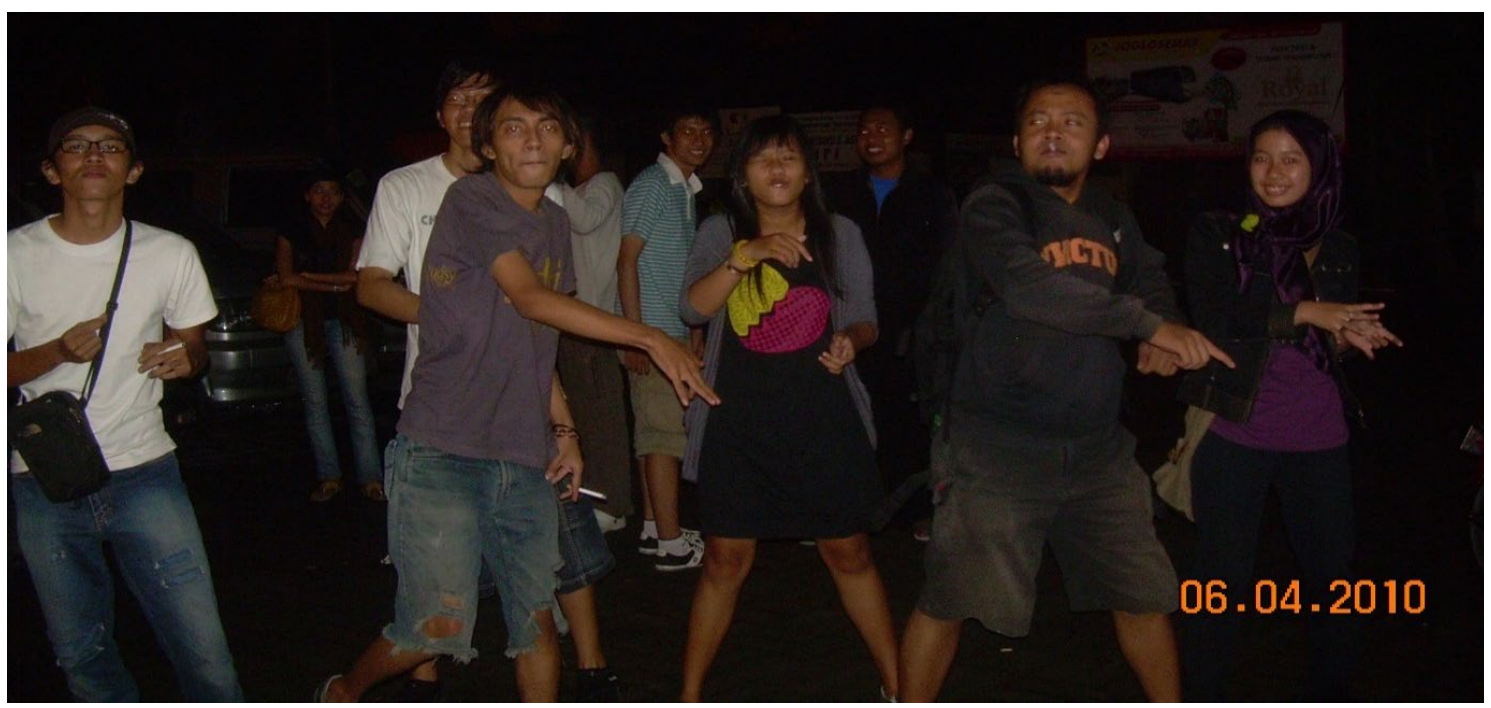

Photo 1. Hang Out and Nurturing Solidarity in Jazz Communities (Photo by Author)

karta. One of the jam session places which become a free public space is Monday Jazz (Jazz Mben Senen) which takes place in the yard of the public gallery owned by the national newspaper which supports freedom of expression and concern about the issue of multiculturalism in Yogyakarta. The reason for creating a public jam session in a public space is not only a solution for limited availability of 'free' public space, it is also intended to facilitate inclusive social interactions between 'North' and 'South 'jazz communities in Yogyakarta (see Sutopo 2010). Furthermore, based on my participant observation, this public jam session also includes other forms of genres outside jazz and participation from non-jazz community members. As explained in the previous subchapter, this reflects the cultural shift of Yogyakarta jazz scenes as more grassroots and inclusive. Although it was through conversion of strategic social capital possessed by senior musicians, the ammunition of laborers which keep the sustainability of the jam session mostly consists of the young members. Since early 2010 until now, Jazz Mben Senen has been regularly held at the same public place and even has reached wider audience as well as publicity in various local, national and international media both online and offline. One thing to be remembered about this endurance is that it does not rely on the funding support of local government from the beginning until now. The continuity and innovation of Monday Jazz is based on the voluntary actions and shared commitment among young members and not only consists of musicians but also fans and others whom sympathize with their youth spirit.

As an alternative public space for jam sessions, Jazz Mben Senen facilitates young musicians to gather inclusively not only in terms of musical jam but also non-musical. The flow of a jam session itself is often based on improvisation and sometimes is well-planned if there is a special occasion related to the music community. Through a jam session, young musicians are able to learn and share musical experiences with senior musicians, fellow young musicians as well as with 'ordinary people' whom spontaneously jump to the stage and jam. As a space of production, jam sessions allow young musicians to reflexively adapt, improvise and learn how to perform in public. What I mean by public is not only for jazz lovers but also non-jazz lovers whom often have a different point of view or cultural taste. Jam sessions have become a strategic space to learn the 'real' situation of dealing with music business; it also facilitates them to do an informal 'apprenticeship' with dominant social agents. In Bourdieusian terminology, jam sessions as a public space is also an important part of building and developing embodiment process (Bourdieu 1993) for young 


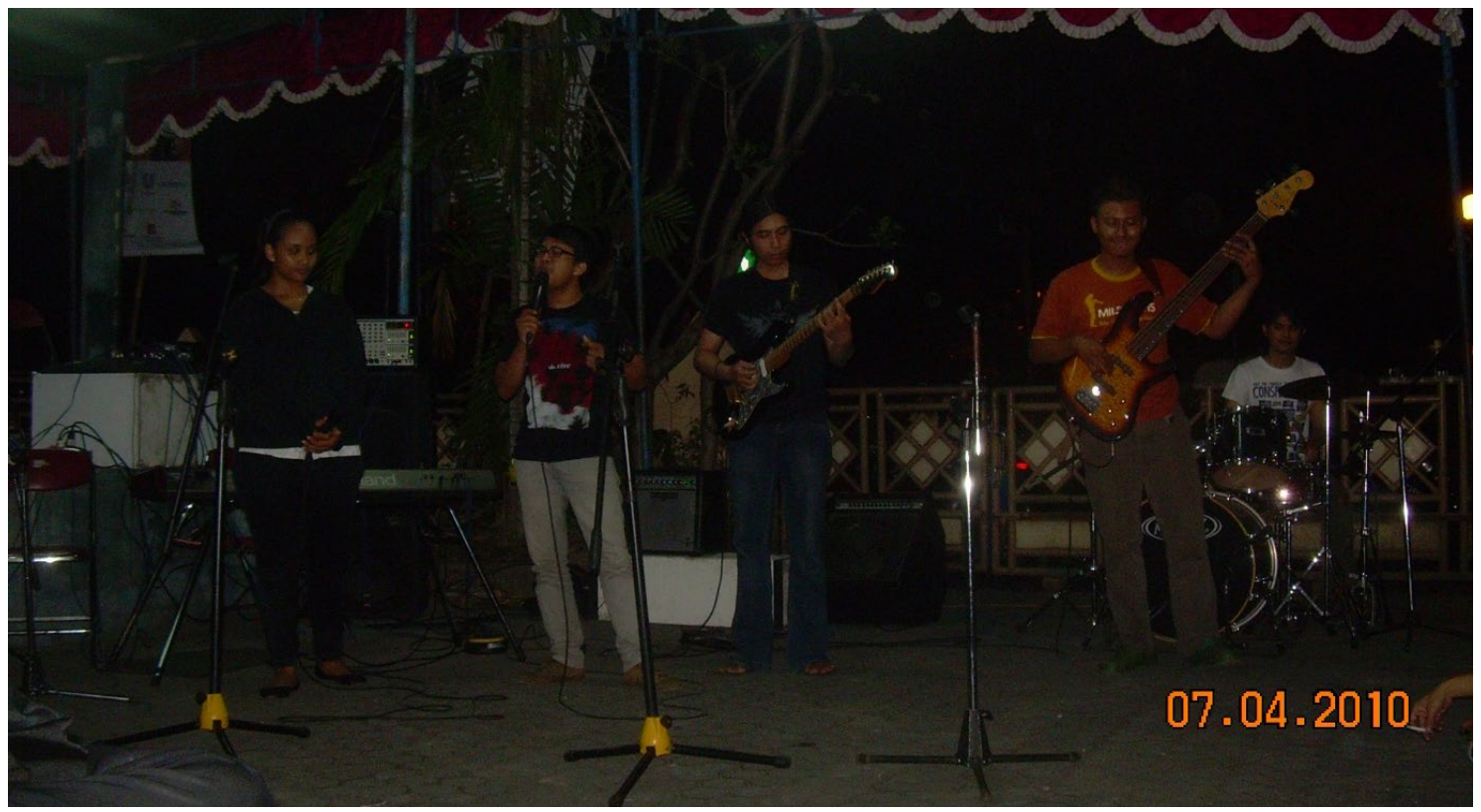

Photo 2. Jazz Mben Senen (Photo by Author)

jazz musicians, not only related to mastering instruments but more important than that, mastering the ability to interact with fluid audiences across the class spectrum. On the other hand, in terms of Do It Yourself (DIY) distribution of music products, the availability of public jam sessions like Jazz Mben Senen also becomes an alternative space to promote and introduce their original artistic products to the public. As it happens elsewhere, nowadays, it is very difficult for DIY bands to distribute and sell their music products in mainstream music retails because they are not considered as a part of the 'major' music label and being stigmatized as relatively non-commercial. However, Jazz Mben Senen serves as an alternative space of distribution not only for young jazz musicians whom produce their own 'idealistic' and original music albums but also for other DIY bands from different music genres. This practical action shows the strong collective spirit and high volume of social capital (Bourdieu 1986) among young musicians who struggle for recognition and sustainability in the Yogyakarta music field.

\section{JAZZ ON THE STREET AND CON- TESTED MEANING OF PUBLIC SPACE}

The creative strategies of young jazz musicians to negotiate against commodifica- tion and privatization of public space are not only manifested through creating and maintaining jazz communities and public jam sessions but they also fluidly and sporadically occupy public streets to jam and performs. Specifically, this sporadic act of resistance is through 'Jazz on the street' (Jazz Sobo Ndalan). For them, streets belong to public and it should not be commercialized by local government or any business institutions. During my observation, it seems like it is an objective condition in Yogyakarta that streets including pedestrian' pavement are occupied by private business. Young jazz musicians through jazz on the street tried to contest and deconstruct (see Derrida 1967) the taken for granted doxa which is continuously reproduced by local government and private business by showing them that they can occupy public streets and have the freedom to express their forms of youth culture. Based on my participant observation, young jazz musicians organized the event collectively. They usually gathered at jazz community several days before and discussed about prospectus space to hold the jazz on the street. They also shared responsibilities among each other, such as: related to sound system, musical instruments, and music repertoires. In addition, sharing the event through social media (Facebook, twit- 


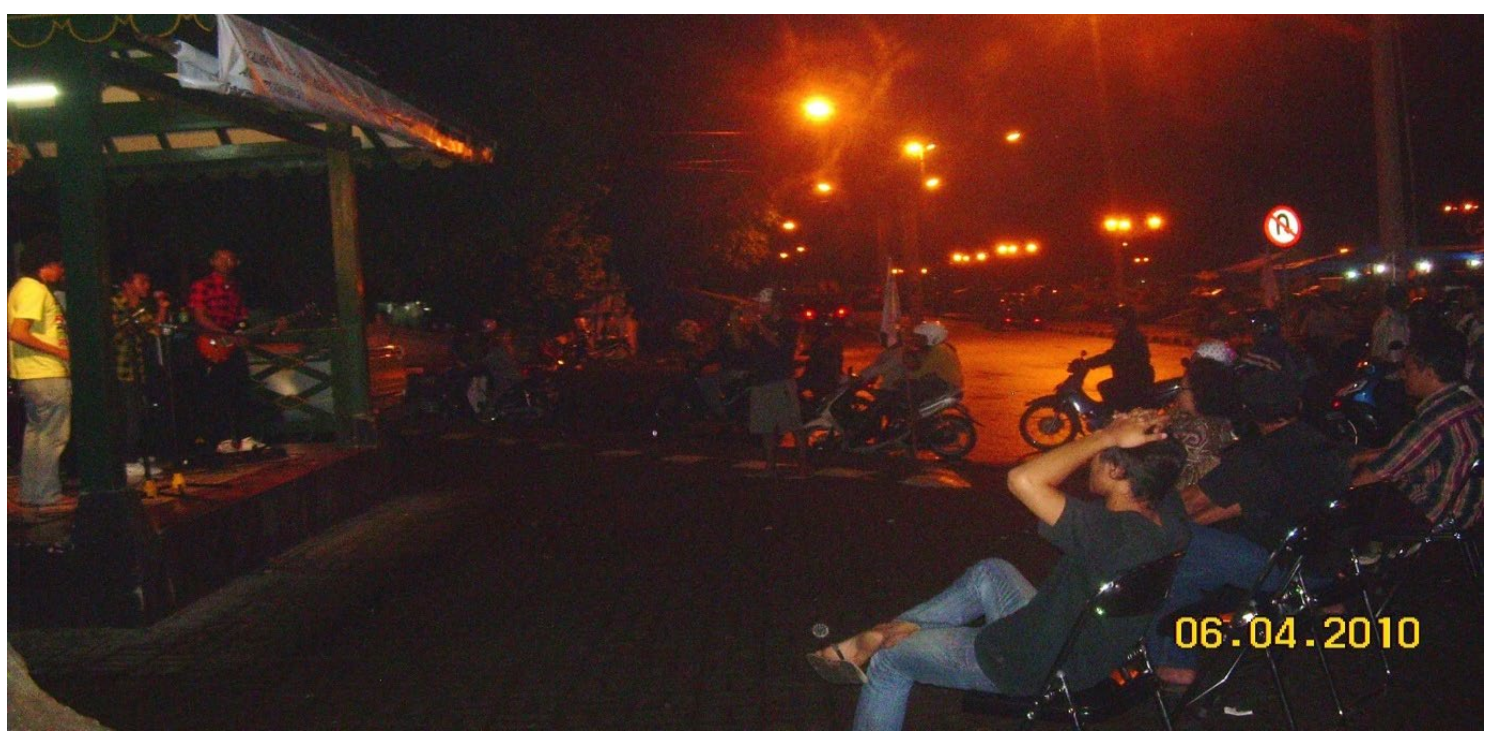

Photo 3. Jazz on the Street (Photo by Author)

ter, Instagram) or through words of mouth is also included. Some young jazz musicians also voluntarily brought some foods and drinks to share with others. Theoretically, this collective action shows not only objective fact of high volume of social capital; deeper than that, it also shows its element of durability (Bourdieu 1986). Durability as an element of social capital is significant as a "glue" for their collective friendship and maintaining the sustainability of the mutual benefit relation among them (see Sutopo et al 2017). It also maintains the sustainability of jazz on the street as an act of resistance.

Strategically, often jazz on the street takes place around Yogyakarta palace (Keraton Yogyakarta), traditional market, central post office and university. They never occupy the same street in every act of resistance; in contrast, they move fluidly and sporadically including in relation to the temporality of their actions. Sometimes they perform in the morning especially on Sunday and sometimes in the late afternoon. This fluidity and sporadic character of jazz on the street not only symbolically represents youth spirit but also they want to show that power/knowledge is decentered (see Foucault 1980). Power/knowledge is no longer centered and monopolized by dominant social agents (local government and private business), instead, they want to show that where there is power, there is resistance! It can be argued that young jazz musicians' fluid and sporadic strategy of resistance reflects the disruption to the regularities of the dominant discourse. It aims to disturb not only the contents of discourse but also the structural basis that gives the contents their meaning (Dant 1991, p. 127).

In Bourdieusian terminology, young jazz musicians' practical action reflects their collective creative strategy to stay and sustain in the game that they have deeply committed and belief that the game does have a meaning for them (see Bourdieu 2000) ${ }^{7}$. It also reflects the "double structural obstacles" that young jazz musicians have to negotiate in order to maintain their youth culture practice. From different point of view, this act of resistance which manifests through jazz on the street shows young jazz musician's efforts to transform the exclusive image of jazz as previously explained. As they learn more and dig deeper into the history of jazz, and its philosophical roots, as well as being reflexively aware about the process of commodification and privatization of public space (see Bodnar 2015), they start to realize that jazz can be a tool for symbolic resistance against dominant social agents (local government and private busi-

7 For critics on Bourdieu's theory of practice especially from humanist realism perspective see Leahy (2017). 
ness). In other words, young jazz musicians want to contribute to their society through the medium of youth culture. Jazz as a part of youth culture in Yogyakarta can actually be political which derives from the experience of subordination (Blackman 2005, p. 6). Although the characteristic of jazz scenes in Yogyakarta can be best described as a mixture between subculture (Blackman 2005) and post-subculture (Bennett 1999), however, in this case, jazz on the street represents the subculture spirit of resistance in Yogyakarta jazz scenes.

\section{CONCLUSION}

The creative strategies of young jazz musicians as explained above show the process of struggle not only in the field of cultural production but also related to rapid changes which surrounds their social environment. The narratives show how young jazz musicians are reflexively aware about the process of commodification and privatization of public space which was constructed by local government and private business. As an implication, it created limited 'free' public spaces for them to nurture their particular forms of youth culture, to learn and accumulate valuable forms of capital as well as to promote themselves to the wider public. However, reflexively, young jazz musicians together with senior and other jazz lovers create and maintain the sustainability of jazz communities and public jam sessions as an alternative space of production. On the other hand, they also fluidly and sporadically resist the taken for granted doxa of commercialization on public streets through initiation of jazz on the street (Jazz Sobo Ndalan). These two combinations represent young jazz musicians' reflexive strategy not only for the purpose of individual interest but more than that, they want to make a valuable contribution to public and keep the spirit of youth resistance alive!

\section{REFERENCES}

Aspinall, E and Mark, T. B, 2001. The Break-up of Indonesia? Nationalism after Decolonization and the Limits of the Nation-state in PostCold War Southeast Asia, Third World Quarterly, 22(6), pp. 1003-1024.

Baay, R. 2017. Nyai E Pergundikan di Hindia Belanda. Komunitas Bambu, Jakarta.

Bhabha, H. K. 2004. The Location of Culture. Routledge, London.

Bennett, A. 1999. Subcultures or Neo-tribes? Rethinking the Relationship between Youth, Style and Musical Taste, Sociology, 33(3), pp. 599-617.

Bennett, A. 200o. Popular Music and Youth Culture: Music, Identity and Place. McMillan, London.

Bennett, A. 2002. Researching Youth Culture and Popular Music: a Methodological Critique, The British Journal of Sociology, 53(2), pp. 451-466.

Bennett, A \& Richard A. P (ed) 2004. Music Scenes: Local, Trans local, and Virtual. Vanderbilt University Press, Nashville.

Blackman, S. 2005. Youth Subcultural Theory: a Critical Engagement with the Concept, its Origins and Politics, from the Chicago School to Postmodernism, Journal of Youth Studies, 8(1), pp. 1-20.

Bloustien, G and Margaret, P. 2011. Youth, Music and Creative Cultures: Playing for Life. Palgrave McMillan, London.

Bodnar, J. 2015. Reclaiming Public Space, Urban Studies, 52(12), pp. 2090-2104.

Bourdieu, P. 1984. Distinction: A Social Critique of the Judgement of Taste, Translated by Richard Nice. Harvard University Press, Cambridge.

Bourdieu, P .1986, 'The Forms of Capital', in J. Richardson (ed.) Handbook of Theory and Research for the Sociology of Education. Greenwood, New York, pp. 81-93.

Bourdieu, P. 1993. The Field of Cultural Production: Essays on Art and Literature, Edited and Introduced by Randal Johnson. Columbia University Press, Columbia.

Bourdieu, P. 1998. Practical Reason. Polity Press, Cambridge.

Bourdieu, P. 200o. Pascalian Meditations. Stanford University Press, USA.

Bourdieu, P \& Wacquant L. 1992. an Invitation to Reflexive Sociology. Polity Press, Cambridge.

Dant, T. 1991. Knowledge, Ideology and Discourse: A Sociological Perspective. Routledge, London.

Derrida, J. 1967. Of Grammatology. John Hopkins University Press, USA.

Farrugia, D. 2014. Towards a Spatialised Youth Sociology: The Rural and The Urban in Times of Change. Journal of Youth Studies, 17(3), pp. 293-307.

Foucault, M. 1980. Power/Knowledge: Selected Interviews and Other Writings. Vintage, USA.

Fraser, A., Batchelor, S., Ling, L. \& Whittaker, L. 2017. City as Lens: (Re)Imagining Youth in Glasgow and Hong Kong. Young, 25(3), pp. 235-251.

Hodkinson, P. 2002. Goth, Identity, Style and Subculture. Berg Publisher, UK.

Lamaison, P. 1986. From Rules to Strategies: An Interview with Pierre Bourdieu. Cultural Anthro- 
pology, 1(1), pp. 110-120.

Leahy, T. 2017. Humanist Realism for Sociologist. Routledge, London.

Myles, J. F. 2004. From Doxa to Experience: Issues in Bourdieu's adoption of Husserlian phenomenology. Theory, Culture E Society, 21(2), pp. 91-107.

Perdue, W. D. 1986. Sociological Theory. Mayfield Publishing Company, California.

Setiawan, D., Haryono, T., \& Burhan, A. 2014. The Public Space of Jogja Fashion Week Carnival and Cosplay Clothing in Yogyakarta. Jurnal Komunitas, 6(2), pp. 189-196.

Sutopo, O. R. 2010. Dinamika Kekuasaan dalam Komunitas Jazz Yogyakarta 2002-2010, Jurnal Ilmu Sosial dan Ilmu Politik, 14(1), pp. 83-106.

Sutopo, O. R. 2012, Transformasi Jazz Yogyakarta: Dari Hibriditas Menjadi Komoditas, Jurnal Sosiologi Masyarakat, 17(1), pp.65-84.

Sutopo, O. R., Threadgold, S. \& Nilan, P. 2017. Young
Indonesian Musicians, Strategic Social Capital, Reflexivity and Timing, Sociological Research Online 22(3).

Sweetman, P. 2003. Twenty First Century Dis-ease? Habitual Reflexivity of Reflexive Habitus. The Sociological Review, 51(4), pp. 528-549.

Threadgold, S \& Nilan, P. 2009. Reflexivity of Contemporary Youth, Risk and Cultural Capital. Current Sociology, 57(1), pp. 47-68.

Urry, J. 200o. Sociology Beyond Societies: Mobilities for the Twenty First Century. Routledge, London.

Wacquant, L. 2004. Body E Soul. Oxford University Press, Oxford.

Wacquant, L. 2014. Homines in Extremis: What Fighting Scholars Teach Us about Habitus. Body $\mathcal{E}$ Society, 2o(2), pp. 3-17.

Wyn, J \& White, R. 20oo. Negotiating Social Change: The Paradox of Youth. Youth E Society 32(2), pp. 165-183. 